\title{
Military Expenditure and Economic Growth in China
}

Submitted 20/02/20, 1st revision 25/03/20, 2nd revision 19/04/20, accepted 08/05/20

\author{
Sampson Agyapong Atuahene ${ }^{1}$, Kong Yusheng ${ }^{2}$, \\ Geoffrey Bentum-Micah ${ }^{3}$, Evans Garti ${ }^{4}$, Alexender Baah ${ }^{5}$
}

\begin{abstract}
:
Purpose: In this study, we contribute to the existing literature by examining the relationship between military spending changes and economic growth in China over the period 1995 to 2018 using Granger causality test. We would also explore short and long run relationship between GDP growth and military expenditure of China.

Approach/Methodology/Design: Data used in this study are yearly data covering the period of 1995 to 2018 and the variables are Gross Domestic product (GDP) and Military Expenditure (ME). Data were collected from World Bank. GDP is at 2010 constant US prices and $M E$ is expressed as a percentage of economic growth. All variables are transformed into the natural logarithmics to obtain growth effects.

Findings: Using causality test, the causal relationship between the variables revealed that the alternative hypothesis should be accepted which is lagged GDP variable (proxy of economic growth) does not cause ME in our first VAR Granger causslity Wald test model. However, we discover and verified that there is one-way causality from economic growth to military spending, but no causality from military spending to economic growth is observed in this study. China's positive economic growth can finance its military expenditure.

Practical Implications: The study will contribute positively to the understanding of influence of GDP on military expenditure for emerging and developed ecconomies.

Originality/value: This study innovates by using Cointegration, E-granger and Granger causality test to find out economic growth causing military expenditure in developing economies like China.
\end{abstract}

Keywords: GDP, military spending, economic growth, Granger causality.

JEL: H5, O47, C23.

Paper Type: Research article.

\footnotetext{
${ }^{1}$ School of Finance and Economics, Jiangsu University, e-mail: 5103181207@stmail.ujs.edu.cn

${ }^{2}$ School of Finance and Economics, Jiangsu University, e-mail: $1000001042 @$ ujs.edu.cn

${ }^{3}$ School of Finance and Economics, Jiangsu University,

e-mail:5103181232@stmail.ujs.edu.cn

${ }^{4}$ School of Finance and Economics, Jiangsu University, e-mail: egarti2018@gmail.com

${ }^{5}$ School of Finance and Economics, Jiangsu University, e-mail: samxin8@gmail.com
} 


\section{Introduction}

Global defense spending lessened from US $\$ 1,613$ billion in 1988 to US $\$ 1,052$ billion in 1996 (Witko, 2003). However, in 2001 to 2012, there was a huge percentage increase in military expenditure worldwide: 51 percent increase from US $\$ 1,146$ billion to US\$1,733 billion (Szymanski, 1973). Most people consider research work on the effects of military expenditure and economic growth as weird. Effects of military spending are divided among two groups; the "pro" group that views military spending as a guarantee of peace, security and welfare, while the "against" group sees such spending as a wasteful enterprise that influences the economy beyond the resources it takes up. Military expenditure is consider as one of the non-developmental expenditure, expenditure of the government, which does not directly help in economic development of the country (Haseeb et al., 2014).

There is remarkably large and growing literature on subject that reflects a continuing lack of consensus. As displayed by academics, there are several ways that military spending may affect the growth of a country (Henderson, 1998). Empirical findings have not produced a conclusive result. Conclusions are that the effect of military spending on economic growth may be negative, or positive, significant or insignificant (Aziz et al., 2017).

The Keynesian income multiplier effect posits that military spending affects economic growth positively (Su et al., 2018), whereas crowding out hypothesis favors a negative growth impact of military spending (Zaman, 2019). Indeed, as there is no agreed theory of growth among economists, there is no standard framework to fit military spending.

In this study, we contribute to the existing literature by examining the relationship between military spending changes and economic growth in China over the period 1995 to 2018 using Granger causality test (World Bank, 2018). We would also explore short and long run relationship between GDP growth and military expenditure of China.

\section{Literature Review}

Most studies carried out during the 1960s and 1970s showed that military spending was more advantageous for financially wealthy countries than it was for less privileged countries (Goode, 2010). Menla and Dimittraki (2014) found positive effects of military spending on economic growth through the accumulation of human capital or derived technologies, while the view that military spending help in improving infrastructure and promoting full employment and the increase in aggregate Keynesian demand was found by Kenny (1983), Aziz and Asadullah, (2017), Kennedy (1983), Menla and Dimitraki (2014). Benoit hypothesis discovered a positive impact of defense expenditure on economic growth for a group of lessdeveloped countries (Benoit, 1978). 


\section{Empirical Analysis}

Primary study of the impact of defense spending on economic growth in Latin America, was suggested that the military burden hampered growth (Reitschuler and Loening, 2005). However, recent studies have shown that the relationship is positive (d'Agostino et al., 2016; Raju and Ahmed, 2019). According to Derouen et al. (2010) defense spending has both positive and negative effects on economic growth in Latin America, but there is no net positive effect.

\subsection{Augmented Solow Model}

The augmented Solow growth model was introduced by Mankiw et al. (1992) and used to measure the effect of military expenditure on growth by Knight et al. (1996). Augier et al., (2017) examined whether defense spending contributed to economic growth in China for the period 1952-2012. They examined the contribution of defense to economic growth using recently released official data on economic activity, defense and public spending. According to Solow's augmented model, a 1\% increase in defense spending increases the rate of economic growth by about $0.15 \%$ to $0.19 \%$.

\subsection{The Feder-Ram model}

Biswas and Ram (1986) adapted Feder's $(1983,1986)$ export-to-growth model for cross-country research on the effects of military expenditure and economic growth. Deger and Sen (1995) described the Feder-Biswas-Ram externality model as "an excellent empirical tool for investigating the impact of military expansion on economic growth." It is generally believed that this method provides a formal justification for single equation growth regression analysis that separates military expenditures as explanatory variables. This analysis is "rooted in neoclassical growth theory" (Mintz and Stevenson, 1995), or at least There is a sufficient foundation in the functional framework of neoclassical production "(Biswas and Ram, 1986). According to Augier (2017), the Feder model does not seem to explain China's economic growth.

\subsection{Two-State Markow-Switching}

According to Menla and Dimitriki (2014), using two state Markov-switching, the relationship between changes in military spending and economic growth depends on the state. According to their results, bearing in mind data from China in the period from 1953 to 2010, changes in military spending negatively affect economic growth during slower growth in higher variance state, while positively in faster growth state that has its variance low. Fritsche et al. (2019) in their work "Government Spending Multipliers in (Un)certain Times" estimated the dynamic effects of government spending shocks, using probabilistic instruments that exploit time-varying volatility in US data. They concluded that the multiplier is significantly smaller when volatility is higher, consistent with theories predicting reduced effectiveness of surprise fiscal interventions in uncertain times. 


\subsection{GMM Technique}

Military spending is not seen as a productive activity that can make a positive contribution to GDP, but has an indirect effect in reducing risk and ensuring stability. Furthermore, as it is considered a major expense in many countries, it could indirectly affect the economy by also increase the level of income via production of military goods and services (Rahman and Siddiqui, 2019). The economy may grow with increasing military spending or vice versa. Rahman and Siddiqui (2019) explored the impact of defense spending on economic growth and per capita income in 85 countries over the past 20 years, from 1998 to 2017. We have used the GMM technique where the models of Rahman and Siddiqui (2019) suggested that the impact of defense spending on economic growth was negative because there was less money left to invest in other areas such as infrastructure, health, education and the production of everyday goods. However, they argue that if arms supplement a country's exports, defense spending becomes favorable to GDP.

\section{An Overview of China's Growth and Defense Policies}

Although China represents over half the region's spending, Russia remains the highest defense spender as a percentage of GDP and government spending. Moreover, the United States has the highest in terms of monetary value (Figure 1). However, we must understand that, not until 1949 China had a retarded due to budget weaknesses and a low rate of public spending (about $9 \%$ of national income). The current revival of interest in China's defense spending and its military modernization needs to shed lit on the relationship between military spending policies and strategies and economic growth in China.

Figure 1. Military expenditures by country

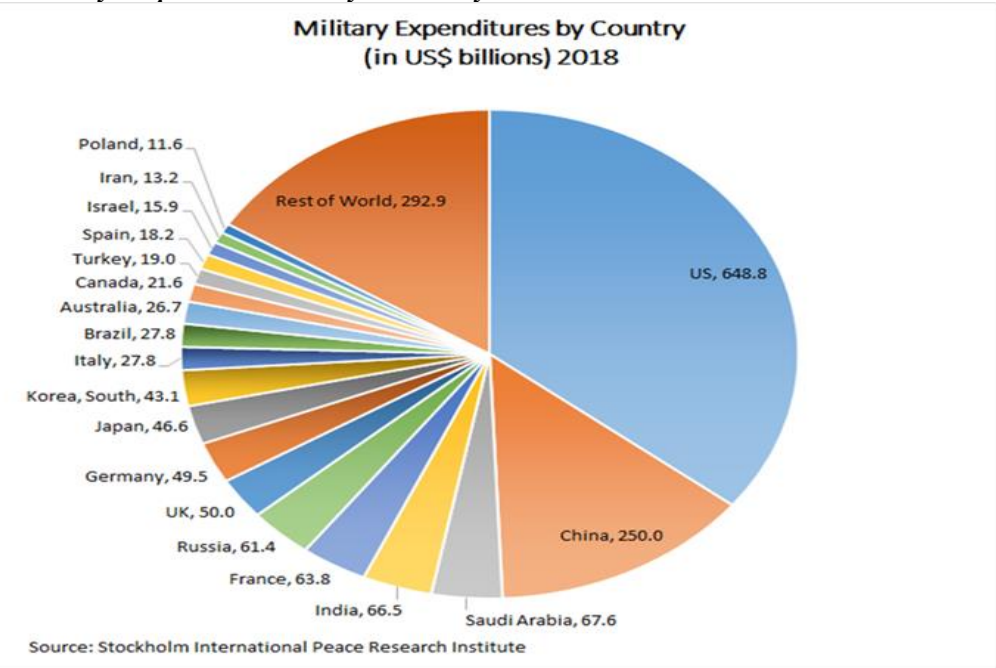

Source: Stockholm International Peace Research Institute. 
Considering the Stockholm International Peace Research Institute, United States and China owns almost 50 percent of the total 2018 military expenditures in the world. Other country mentioning includes India, France and Germany. Critic wants to know the primary motivation of military spending changes of a country. There are lot of factors that can be cited. The factors can be group into two: internal and external factors. The estimated military strength of a potential enemy (if any), the country's geographical neighbors, economic constraints, end of conflicts, forced disarmament, and severe political changes. Other factors include as size of population, technological development and income from exportation of arms. Table 1, shows the general overview of some economic indicators of China.

\subsection{China's Defense Budget}

China's 2017 declared defense budget was CNY1tr (USD151bn) - a 2.1 percent real increase on the 2016 defense budget. In April 2017, China launched its first indigenously built aircraft carrier, with reports another two are planned for construction (Khanna, 2019). China launched its first of four Type-055 cruisers and the seventh Type-815A DONGDIAO-class auxiliary general intelligence ship, which was an improvement on the earlier Type 815. In July 2017, Russia announced it would deliver China an additional four Mi-171E helicopters in 2018.

Table 1. Profile of China

\begin{tabular}{|c|c|}
\hline Country & China \\
\hline Capital & Beijing \\
\hline Population & $1,437,731,640(2020)$ \\
\hline Active armed forces & $2,035,000(2019)$ \\
\hline Reserve personnel & $510,000(2019)$ \\
\hline Land size & $9,598,089 \mathrm{~km}^{2}\left(3,705,843 \mathrm{mi}^{2}\right)$ \\
\hline Currency & $R M B$ \\
\hline Fiscal year & $1^{\text {st }}$ January-December $31^{\text {st }}$ \\
\hline Economy & $\begin{array}{l}\text { Socialist Market, Economy Industries- Includes, Iron } \\
\text { Steel, Petroleum, Cement, Chemical fertilizers, } \\
\text { automobiles electronics and telecommunications }\end{array}$ \\
\hline Income level & Upper middle income \\
\hline Region & East Asia \& Pacific \\
\hline
\end{tabular}

Soucre: World Bank, 2018.

Over the past 10 years, Japan averaged 0.5 per cent annual real economic growth. In 2017, the economy grew by 1.6 per cent, due to a strong recovery in Japanese exports. Japan's economy is experiencing the longest stretch of continuous growth since the mid-1990s. However, a rise in global oil prices, coupled with slow wage growth, has reduced household purchasing power, suggesting consumer spending was not strong in 2017. Japan's economy is forecast to average 1.2 per cent real growth to 2022, according to the World Bank data 2018 (Figure 2). 
Figure 2. Multiply country analysis

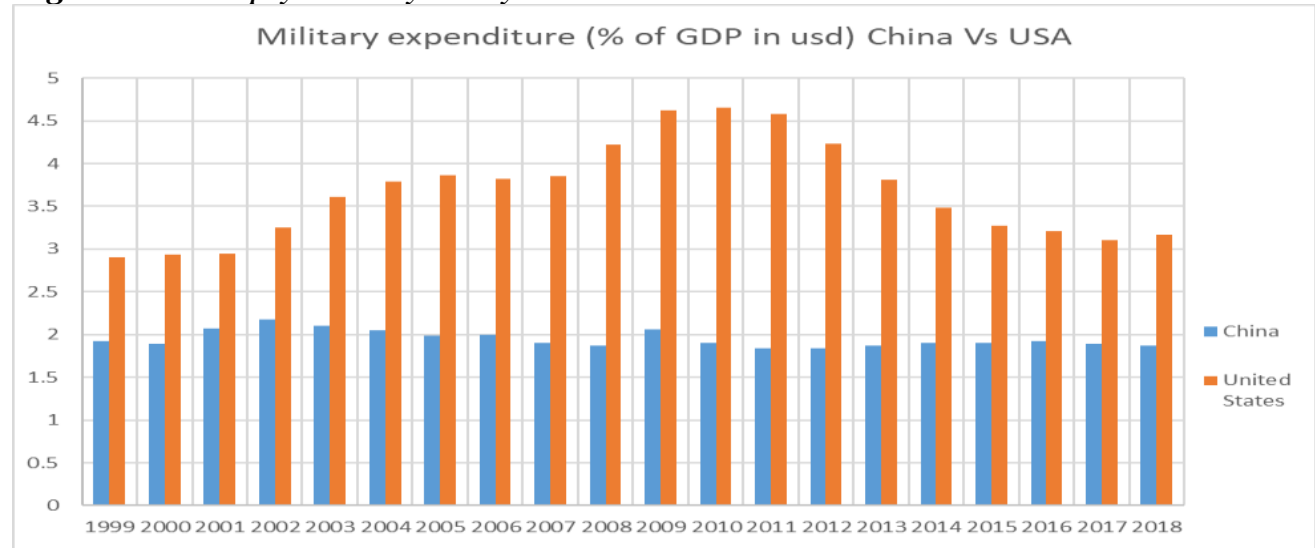

Source: World Bank, 2018.

From Figure 1, two variables were used in the analysis for two countries military expenditure as percentage of GDP. We used the data of GDP growth as the indicator of economic growth and data of military expenditure as percentage of GDP as the value of military expenditure. The data of GDP growth rate is collected from the World Bank Data; (1995-2018) and the data of Military expenditure as a percent of GDP are collected from Stockholm International Peace Research Institute (SIPRI2018). Comparatively we can clearly state that the USA is ahead when it comes to the percentage of its GDP that they pump into the military.

However, is not conclusive since many factors comes into play when dealing with security. The spending of United States rises, peaks at 2010 and falls thereof. In the contrary China has a steady growth. The likeliness observed in China military spending are similar of the one described in the international literature (Figure 3 ).

Figure 3. The Model of Chinese Defense Expenditure

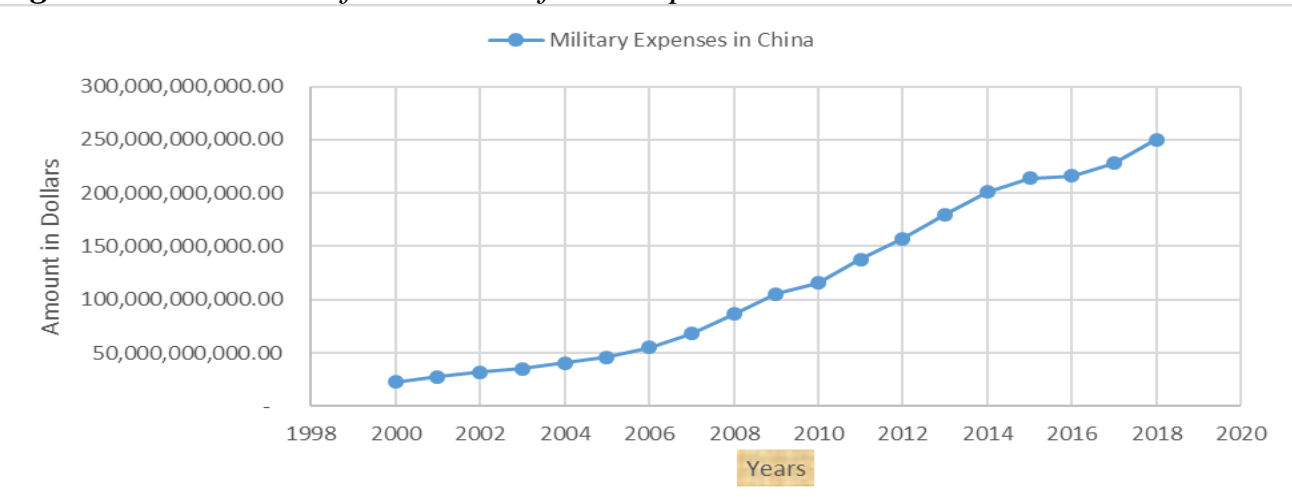

Source: World Bank, 2018. 
Analysis of Figure 3 shows that from the year 2000 there has been an increase in military spending in China. However, the number of army personnel keeps declining. This suggest that the yearly declining in personnel does not match with the expenditure that the Chinese government does on its military.

\section{Methodological Procedures}

Suppose that one is interested in the question of whether or not a vector of economic time series yt 'causes' another vector xt. There will also exist a further vector of variables wt, which provides a context within which the causality question is being asked. With regards to this statement we performed the Augmented Dickey-Fuller (ADF) unit-root tests to determine the order of integration of the variables (Dickey and Fuller, 1981) and employed the Johansen test to estimate the possible long-run equilibrium relationship between these variable (Johansen and Juselius, 1990). Secondly, to investigate the long-run relationship between GDP growth and military expenditure we used Engle-Ganger Co-integration test. At last, Granger causality test is used to analyze the direction of the causal relationship between the variables (Granger, 1988).

\subsection{Empirical Model}

Prior studies suggest that economic growth affects military expenditure in countries like Turkey India, South Africa, and Ghana (Yusheng et al., 2020). We believe that ME can be affected by GDP in the case of China. We adopt the fundamental equation for this study as GDP=f(ME) where ME is a function of GDP. GDP is the proxy for economic growth. The variables can be transferred into the logarithmic forms in order to capture impacts of growth as mentioned before.

Therefore, the proposed model is InGDP $=\beta 0=\beta 1 \operatorname{lnME}+\varepsilon 1$ where at time $t, \operatorname{lnME}$ and $\operatorname{lnGDP}$ are the natural logs of military spending and real income respectively, $\mathrm{et}$ represents the error term, B0 is the constant coefficient which is the intercept of the equation and $\beta 1$ is the coefficient of $\operatorname{lnGDP}$ and represents the slope of the equation.

\subsection{Unit Root Test}

We employ to widely used unit root tests namely Augmented Dickey-Fuller (ADF), to determine the level of integration of the variable under investigation. Enders \& Sandler (1995) handbook of defense economics suggests the most common model for unit roots with trends and intercept which is initial point of the analysis the following :

$$
\Delta y_{t}=a_{0}+\lambda_{y_{t-1}}+a_{2} t+\sum_{i=2}^{p} \beta_{j} \Delta y_{t-i-1}+\varepsilon_{t}
$$

where $\mathrm{y}$ is the dependent variable, is the drift, $\mathrm{t}$ is trend, $\varepsilon$ is a Gaussian white noise and $\mathrm{p}$ represents the lag level. In order to ensure that the errors are white noise, the 
number of lags " $p$ " of the dependent variable should be determined by using the AKaike Information Criteria AIC or some other alternative criteria. ADF tests apply t-test for $\lambda$. The Null hypothesis of these tests is that the series is non-stationary. If the series is stationary at level 0 the series is called integrated of order zero, $\mathrm{I}(0)$. When the series is stationary at first differences, is called integrated of order one, $\mathrm{I}(1)$.

\subsection{Co-Integration Test}

In this part, the possible long-run equilibrium relationship between the variables is investigated. The present research is based on Johansen methodology that is used to test co-integration among variables having the same order of integration. Minimum one co-integrating vector is required in order to have co-integration between the variables. Johansen test takes its initial point in the vector auto regression (VAR) of order $\mathrm{p}$ given by:

$$
y_{t}=\mu+A_{1} y_{t-1}+\cdots+A_{p} y_{t-p}+\varepsilon_{t} \text { for } \mathrm{t}=1, \ldots, \mathrm{T}
$$

where yt, yt-1..,yt-p are vectors of level and lagged values of $p$ variables respectively which are $\mathrm{I}(1)$ in the mode; A1...,Ap are coefficient matrices with (PXP) dimensions; $\mu$ is an intercept vector, $\varepsilon$ is a vector of random errors.

Johansen and Juselius (1990) suggest that trace statistics are obtained by using Eigen values. The trace statistic ( $\lambda$ trace) could be estimated by the formula below:

$\lambda \operatorname{trace}=-\mathrm{T} \Sigma \operatorname{Ln}(1-\lambda \mathrm{t}), \mathrm{i}=\mathrm{r}+1, \ldots \mathrm{n}-1$

The null hypotheses are given as follows;
$\mathrm{H} 0: \mathrm{v}=0$
$\mathrm{H} 0: \mathrm{v} \geq 1$
$\mathrm{H} 0: \mathrm{v} \leq=1$
$\mathrm{H} 0: \mathrm{v} \geq 2$
H0: $v \leq=2$
$\mathrm{H} 0: \mathrm{v} \geq 3$

One important limitation of Granger causality is that when $\mathrm{X}(\mathrm{t})$ is serially correlated, the impact of $\mathrm{x}(\mathrm{t}-1)$ on $\mathrm{y}(\mathrm{t})$ will be simply a consequence of the impact.

\subsection{Granger Causality Test}

This test is performed in order to identify the direction of the causal relationship between ME and GDP. The casual relationships can be either unidirectional or bidirectional. This test estimates the following equations assuming there is no correlation between ult and $\mathrm{u} 2 \mathrm{t}$.

$$
G D P_{t}=\sum_{i=1}^{n} a_{i} M E_{t-i}+\sum_{j=1}^{n} \beta_{j} G D P_{t-j}+u_{1 t}
$$




$$
M E_{t}=\sum_{n=1}^{n} \lambda_{i} M E_{t-i}+\sum_{j=1}^{n} \delta_{j} G D P_{t-j}+u_{2 t}
$$

\section{Analysis of Results}

Table 2 describes the main characteristics of the dependent, independent and control variables relating to the main hypothesis. The China's economic growth is represented by its's GDP and the military spending by a function of GDP. However, to bring these two variables into a common base for analysis purposes we found the natural logarithms of both variables. The descriptive statistics are presented in Table 2 and the unit root test of Dickey-Fuller in Table 3. The variable of GDP has an average value of 28.0114 and standard deviation 1.08812. The variable of ME has an average value of 24.8561 and standard deviation of 1.0094 .

Table 2. Descriptive statistics

\begin{tabular}{|l|l|l|l|l|l|}
\hline Variables & Observations & Average & Stand. Deviat & Minimum & Maximum \\
\hline gdpus 1 & 24 & 28.0114 & 1.088122 & 26.43063 & 29.47913 \\
\hline Mex & 24 & 24.85619 & 1.009409 & 23.25746 & 26.24471 \\
\hline gdpus & 24 & $2.39 e+12$ & $2.09 e+12$ & $3.01 e+11$ & $6.35 e+12$ \\
\hline ME & 24 & $9.59 e+10$ & $8.11 e+10$ & $1.26 e+10$ & $2.50 e+11$ \\
\hline
\end{tabular}

Source: Own calculations.

Tabel 3. ADF test for Military expenditure

\begin{tabular}{|c|c|c|c|c|}
\hline \multicolumn{5}{|c|}{$\begin{array}{c}\text { Dickey-Fuller test for unit root } \quad \text { Number of obs }=23 \\
\qquad----- \text { Interpolated Dickey-Fuller -------- }\end{array}$} \\
\hline & $\begin{array}{l}\text { Test } \\
\text { Statistic }\end{array}$ & $\begin{array}{l}\text { 1\% Critical } \\
\text { Value }\end{array}$ & $\begin{array}{l}\text { d Dickey-Ful } \\
5 \% \text { Critical } \\
\text { Value }\end{array}$ & $\begin{array}{l}\text { er ------- } \\
10 \% \text { Critical } \\
\text { Value }\end{array}$ \\
\hline $\mathrm{Z}(\mathrm{t})$ & -0.610 & -3.750 & -3.000 & -2.630 \\
\hline
\end{tabular}

Source: Own calculations.

According to ADF, series are stationary at the first differences which means series are integrated of order one, (1). We perform Dickey- Fuller test to verify whether both variables are integrated on order 1 i.e., non-stationary in levels but stationary in differences. Using the ADF test we do not reject the null hypothesis of the unit root which means that military expenditure is non-stationary. This is because the ADF test statistic $\mathrm{z}(\mathrm{t}) 0.610$ does not surpass any of the value of the critical values in absolute terms.

\subsection{Co-Integration Analysis}

The general rule is that when two or more variable are co-integrate it means that they are individually non-stationary but a linear combination of those variables is stationary. We can infer that linear combination as a long-run study states equilibrium level. Any deviation from that level can be used to predict future 
corrections using error correction models that take advantage of co-integration. We are looking at whether or not military expenditure is co-integrated with economic growth in general (Table 4).

Table 4. Engle-Granger test for Co-integration for both values

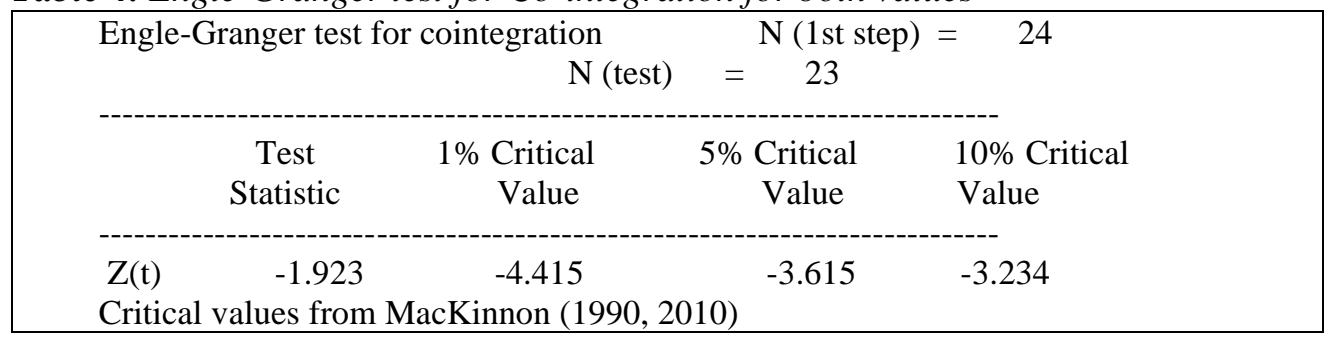

Source: Own calculations.

From Table 4, the test statistic for our observations came with the correct critical values at $1 \%, 5 \%$ and $10 \%$ critical level. Engle-Granger test statistic value is significant at all levels. This verify the integration of the variables. This means that there is a long-term relationship economic growth and military expenditure. Table 5 presents the Johansen test for cointegration.

Table 5. Johansen tests for cointegration

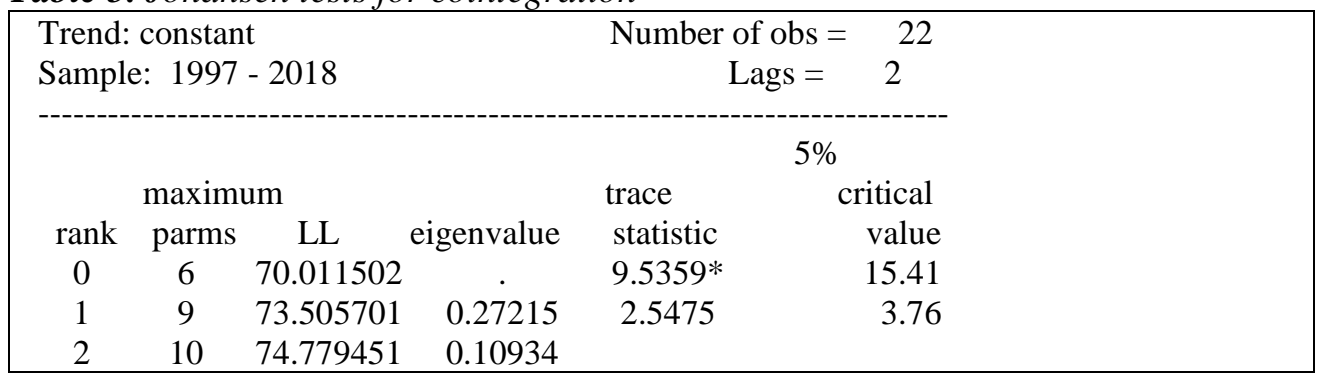

Source: Own calculations.

Looking at Table 5, after performing the unit root test, we found that all the series are stationary at their first differences. Thus, Johansen co-integration analysis is applied in order to check the possible long-run equilibrium relationship among variables. According to Johansen co-integration test, the null hypothesis that there is no co-integrating vector in the proposed model is rejected and concluded that there is at least one co-integrating vector. In other words, there is a long-run equilibrium relationship between military expenditure and economic growth in China. Table 6 presents the vector autoregression results.

Table 6. Vector autoregression

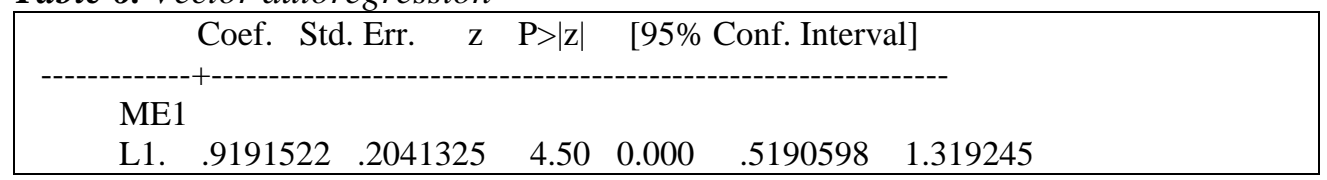




\begin{tabular}{|lllllll|}
\hline L2. & .0137897 & .1804146 & 0.08 & 0.939 & -.3398164 & .3673958 \\
GDP & & & & & & \\
L1. & .5019792 & .1292351 & 3.88 & 0.000 & .248683 & .7552754 \\
L2. &. .4540113 & .1270817 & -3.57 & 0.000 & -.7030868 & -.2049357 \\
cons & .3939915 & .2367871 & 1.66 & 0.096 & -.0701028 & .8580858 \\
----------------- & \\
ME1 & & & & & \\
L1. & .2352342 & .2992519 & 0.79 & 0.432 & -.3512888 & .8217572 \\
L2. & .0954953 & .2644822 & 0.36 & 0.718 & -.4228804 & .6138709 \\
GDP & & & & & & \\
L1. & 1.50882 & .1894547 & 7.96 & 0.000 & 1.137496 & 1.880145 \\
L2.| -.8194506 & .1862978 & -4.40 & 0.000 & -1.184588 & -.4543136 \\
cons & .5144498 & .3471226 & 1.48 & 0.138 & -.165898 & 1.194798 \\
\hline
\end{tabular}

Source: Own calculations.

In Table 6, per our VAR model-1 ME1 is the dependent variable and ME1 L1, ME L2, GDPL1 and GDPL2 are the independent variables. The first null hypothesis is that whether GDPL1 and GDPL2 can cause military expenditure or not. Also, we analyzed whether in the second model where GDP is the dependent variable, our hypothesis is that ME1 L1 and ME L2 can cause economic growth (GDP). We took 2 years lag of the variables to run our vector auto regression model with L1= lagged one period and L2=lagged two periods. Table 7 presents the Granger Wald causality test.

Table 7. Granger causality Wald test

\begin{tabular}{|l|l|l|l|l|}
\hline Equation & Excluded & chi2 & df & Prob > chi2 \\
\hline GDP & Mex & 5.9171 & 2 & 0.052 \\
\hline GDP & ALL & 5.9171 & 2 & 0.052 \\
\hline ME1 & GDP & 15.873 & 2 & 0.000 \\
\hline ME1 & ALL & 15.873 & 2 & 0.000 \\
\hline
\end{tabular}

Source: Own calculations.

Co-integration relationship between variables is confirmed by the Johansen method. Granger causality tests should be run in order to find the direction of the causal relationship among variables. Findings are shown in Table 7 showing that:

A) The null hypothesis will be that lagged ME1 variable does not cause GDP.

B) Alternative hypothesis will be that lagged ME1does cause GDP.

From our analysis, the probability value is $5.2 \%$ greater than $5 \%$. Therefore cannot reject the null hypothesis. We accept the null hypothesis meaning that, lagged ME1 variable does not cause GDP. That is military expenditure does not cause economic growth China. Furthermore, when consider both variables GDP and ME1 the probability value is $5.2 \%$ meaning that both lagged ME1 and lagged GDP do not cause economic growth (GDP) as a whole. 
However, in VAR model 2, the Granger causality Wald test null hypothesis will be that lagged GDP variable does not cause ME1. Alternative hypothesis will be that lagged GDP does cause ME1. By considering the probability value which is less than $5 \%$ we reject the null hypothesis and accept the alternative hypothesis meaning that lagged GDP causes MEI. Also taking into account both variables at model-2, both GDP and ME1, can cause GDP as a whole.

\section{Conclusion}

The purpose of this study is to investigate the causal relationship between military spending and economic growth in China using annual data from 1995 to 2018. Our empirical results indicate that military spending and economic growth have a longterm equilibrium relationship. There is one-way causality from economic growth to military spending, but no causality from military spending to economic growth is observed in this study. There are several previous studies that contradict (Karagol, 2006; Kollias and Makrydakis, 1997) and in agreement with our empirical findings (Abu-Bader and Abu-Qarn, 2003). Although, given the lack of consensus in the literature on the causal relationship between military spending and economic growth, the conflicting results in the case of China are not surprising but still deserve a plausible explanation. One of the possible explanations for the contradictory results could be due to the different period of the studies. Our results can also be explained by the country's macroeconomic fundamentals.

China still imports, although many arms are producing in China, is the world's sixth largest arms' importer. However, it has been a net arms' exporter for many years in this decade. China's success flows from its massive investment in research and development (R\&D) well over 2\% of GDP. Therefore, with a higher GDP growth rate China can finance its military expenditures.

It has been argued that apart from mainland, China has a critical geographical position and other administrative land under its protection such as Taiwan, Macuo, Hong-Kong, that should always be aware of the importance of military power and spend its resources to improve its military strength (Chao, 2003). Our findings reveal that economic growth does cause military spending of China. This finding implies that primary concern of the government should be to promote economic growth, which in turn provides resources to finance higher military expenditures.

\section{References:}

Abu-Bader, S., Abu-Qarn, A.S. 2003. Government expenditures, military spending and economic growth: causality evidence from Egypt, Israel, and Syria. Journal of Policy Modeling, 25(6-7), 567-583.

Augier, M., McNab, R., Guo, J., Karber, P. 2017. Defense spending and economic growth: evidence from China, 1952-2012. Defence and Peace Economics, 28(1), 65-90. https://doi.org/10.1080/10242694.2015.1099204. 
Benoit, E. 1978. Growth and defense in developing countries. Economic development and cultural change, 26(2), 271-280. https://doi.org/10.1086/451015.

Biswas, B., Ram, R. 1986. Military expenditures and economic growth in less developed countries: An augmented model and further evidence. Economic Development and Cultural Change, 34(2), 361-372.

Aziz, N., Asadullah, M. 2017. Military spending, armed conflict and economic growth in developing countries in the post-Cold War era. Journal of Economic Studies, Vol. 44 No. 1, 47-68. https://doi.org/10.1108/JES-01-2015-0021.

Chao, C. 2003. Will economic integration between mainland China and Taiwan lead to a congenial political culture? Asian Survey, 43(2), 280-304.

d'Agostino, G., Dunne, D., et al. 2016. Government spending, corruption and economic growth. World Development, 84, 190-205.

Deger, S., Sen, S. 1995. Military expenditure and developing countries. Handbook of defense economics, 1, 275-307.

DeRouen Jr, K., Ferguson, M.J., Norton, S., Park, Y.H., Lea, J., Streat-Bartlett, A. 2010. Civil war peace agreement implementation and state capacity. Journal of Peace Research, 47(3), 333-346.

Dickey, D., Fuller, W. 1981. Likelihood ratio statistics for autoregressive time series with a unit root. 1057-1072. Econometrica Vol. 49, No. 4, 1057-1072.

Enders, W., Sandler, T. 1995. Terrorism: Theory and applications. Handbooks in Defense Economics 1, 213-249. https://doi.org/10.1016/S1574-0013(05)80011-0.

Fritsche, J.P., Klein, M., Rieth, M. 2012. Government Spending Multipliers in (Un) certain Times. NY.

Goode, R. 2010. Government finance in developing countries. USA, Brookings Institute Press.

Granger, C.W. 1988. Causality, cointegration, and control. Journal of Economic Dynamics Control, 12(2-3), 551-559.

Haseeb, N., et al. 2014. The macroeconomic impact of defense expenditure on economic growth of Pakistan: An econometric approach. Asian Social Science, 10(4), 203-213.

Henderson, E. 1998. Military spending and poverty. The Journal of Politics, 60(2), 503-520.

Johansen, S., Juselius, K. 1990. Maximum likelihood estimation and inference on cointegration - with applications to the demand for money. Oxford Bulletin of Economics statistics, 52(2), 169-210.

Karagol, E. 2006. The relationship between external debt, defence expenditures and GNP revisited: The case of Turkey. Defenc Peace Economics, 17(1), 47-57.

Kennedy, G. 1983. Defense economics. London, Duckworth.

Kenny, L.W. 1983. The accumulation of human capital during marriage by males. Economic Inquiry, 21(2), 223-232. https://doi.org/10.1111/j.1465-7295.1983.tb00627.x.

Khanna, M. 2019. Understanding China's naval ship building industry-lessons India can learn. Maritime Affairs: Journal of the National Maritime Foundation of India, 15(1), 1-14.

Kollias, C., Makrydakis, S. 1997. Is there a Greek-Turkish arms race? Evidence from cointegration and causality tests. Defence Peace Economics, 8(4), 355-379.

Menla, M., Dimitraki, D. 2014. Military spending and economic growth in China: a regimeswitching analysis. Applied Economics, 46(28), 3408-3420. https://doi.org/10.1080/00036846.2014.929626.

Mintz, A., Stevenson, R.T. 1995. Defense expenditures, economic growth, and the peace dividend: A Longitudinal Analysis of 103 Countries. Journal of Conflict Resolution, 39(2), 283-305. 
Rahman, T., Siddiqui, D. 2019. The Effect of Military Spending on Economic Growth in the Presence of Arms Trade: A Global Analysis. Available at SSRN 3401331.

Raju, M., Ahmed. H., et al. 2019. Effect of military expenditure on economic growth: evidences from India Pakistan and China using cointegration and causality analysis. Asian Journal of German European Studies, 4(1), 3-15.

Reitschuler, G., Loening, J. 2005. Modeling the defense-growth nexus in Guatemala. World Development, 33(3), 513-526. https://doi.org/10.1016/j.worlddev.2004.08.008.

$\mathrm{Su}, \mathrm{C}$., Xu,Y. 2018. Dynamic causalities between defense expenditure and economic growth in China: evidence from rolling Granger causality test. Defence and Peace Economics, 1-18. https://doi.org/10.1080/10242694.2018.1505583.

Szymanski, A. 1973. Military spending and economic stagnation. American Journal of Sociology, 79(1), 1-14.

Witko, C. 2003. Cold war belligerence and US public opinion toward defense spending. American Politics Resesarch Journal, 31(4), 379-403. https://doi.org/10.1177/1532673X03031004003.

World Bank. 2018. World Bank open data. TW Bank 2018. https://data.worldbank.org/country/china?view=chart.

Yusheng, K., Atuahene, A. 2020. Impact of Foreign Direct Investment Inflows on Economic Growth; the Case of the Republic of Seychelles. At SSRN 3530161.

Zaman, K. 2019. Does higher military spending affect business regulatory and growth specific measures? Evidence from the group of seven (G-7) countries. Economia Politica-springer, 36(1), 323-348. https://doi.org/10.1007/s40888-018-00138-0. 